\title{
Atypical malignant hyperthermia with persistent hyper- kalaemia during renal transplantation
}

A 35 -year-old $110 \mathrm{~kg}$ male developed marked hyperkalaemia, hyponatraemia, hypercapnia and hyperthermia during livingrelated renal transplantation under anaesthesia with oxygennitrous oxide, isoflurane and muscle relaxation with atracurium. This is the first report of successfully treated malignant hyperthermia triggered by isoflurane during renal transplantation with early appearance and persistent (to 12 hours after surgery) electrolyte abnormalities.

Malignant hyperthermia $(\mathrm{MH})$ is a hypermetabolic state that can be triggered by a variety of stresses and agents including several anaesthetics. ${ }^{1-4}$ We describe the case of a living-related renal transplant recipient under isoflurane anaesthesia with an atypical manifestation of $\mathrm{MH}$ in which severe hyperkalaernia and hypercapnia occurred but serum levels of creatine phosphokinase (CPK) did not increase greatly.

\section{Case report}

A 35-year-old 110-kg man in chronic tenal failure from medullary cystic kidney disease was scheduled to receive a kidney from his 27-year-old brother. The patient had had three previous operations without apparent difficulty: two (repair of a knee injury and an appendectomy) under general anaesthesia (for which records were not available) and a more recent procedure under local anaesthesia (revision of an arteriovenous fistula). He had no other

\section{Key words}

COMPLICATIONS: malignant hyperthermia, hyperkalaemia; SURGERY; renal transplantation.

From the Department of Anesthesiology, The Ohio State University College of Medicine, Columbus, Ohio.

Address correspondence to: Dr. E. Goldman, Department of Anesthesiology, The Ohio State University College of Medicine, N-429 Doan Hall, 410 W. 10th Ave, Columbus, Ohio 43210 medical problems. His ECG showed normal sinus thythm, and a chest $x$-ray was rormal. Dialysis was performed $24 \mathrm{hr}$ before surgery; at the end of the dialysis, the serum potassium level was $4.8 \mathrm{mEq} \cdot \mathrm{L}^{-1}$. At this time he was given $200 \mathrm{mg}$ of axathioprine and $100 \mathrm{mg}$ prednisone IV. Two hours before surgery, the haemoglobin concentration was $8.2 \mathrm{~g} \cdot \mathrm{L}^{-1}$, haematocrit 24 per cent, BUN $79 \mathrm{mg} \cdot \mathrm{dl}^{-1}$, serum creatinine $15.4 \mathrm{mg} \cdot \mathrm{dl}^{-1}$, serum potassium $4.5 \mathrm{mEq} \cdot \mathrm{L}^{-1}$ and serum sodium $139 \mathrm{mEq} \cdot \mathrm{L}^{-1}$.

On arrival at the operating room at 0900 , the patient had a pulse rate of 70 beats $\cdot \mathrm{min}^{-1}$ and arterial blood pressure of $122 / 83 \mathrm{mmHg}$. Monitors included an ECG, a finger plethysmograph, an oxygen analyzer (Hewlett-Packard), a central venous pressure catheter, Dinamap blood pressure cuff, Portex oesophageal stethoscope with a thermistor, a peripheral nerve stimulator, and end-tidal carbon dioxide $\left(\mathrm{PETCO}_{2}\right)$ levels (Hewlett-Packard). Induction was with $400 \mathrm{mg}$ of thiopentone and $100 \mu \mathrm{g}$ of fentanyl. Tracheal intubation was facilitated by administration of $50 \mathrm{mg}$ of atracurium. Anaesthesia was maintained with nitrous oxide and oxygen ( $2 \mathrm{~L} \cdot \min ^{-1}$ total flow) and 0.5 to 1.0 per cent isoflurane. Additional doses of atracurium were added as needed, to a total of $150 \mathrm{mg}$. The last dose of atracurium ( $30 \mathrm{mg}$ ) was given at 12:00. No muscle rigidity was observed either during induction or throughout the case. Ventilation was controlled with a semiclosed system (Drager Narkomed II ventilator).

The first two hours of the surgery were uneventful. Blood pressure was $120-145 \mathrm{mmHg}$ systolic and $70-85$ $\mathrm{mmHg}$ diastolic, pulse rate was $60-70$ beats $\cdot \mathrm{min}^{-1}$, $\mathrm{PETCO}_{2}$ was $32-35 \mathrm{mmHg}$, central venous pressure was $15-20 \mathrm{~cm} \mathrm{H}_{2} \mathrm{O}$ and oesophageal temperature was $36.2^{\circ} \mathrm{C}$. At 1100 the potassium increased to $6.7 \mathrm{mEq}$ $\mathrm{L}^{-1}$. The table shows the changes that occurred in arterial and venous blood gases and electrolytes.

At $1210 \mathrm{PeTCO}_{2}$ bad increased from a previous average of $34 \mathrm{mmHg}$ to $69 \mathrm{mmHg}$ in about five minutes without evidence of circuit malfunction and potassium had increased to $7.3 \mathrm{mEq} \cdot \mathrm{L}^{-1}$ The patient was ventilated 
manually $\left(\mathrm{FIO}_{2} \mathrm{l} .0\right)$ requiring a rapid ventilatory rate and a tidal volume of about one litre to keep $\mathrm{PETCO}_{2}$ at 55 $\mathrm{mmHg}$. At 1215, the venous $\mathrm{PO}_{2}$ of $20 \mathrm{mmHg}$ indicated an increased $A-V$ difference for $\mathrm{O}_{2}$ due to either decreased cardiac output or increased $\mathrm{O}_{2}$ uptake. Considering the stability of blood pressure and increasing $\mathrm{PETCO}_{2}$, the diagnosis of malignant hyperthermia was likely; it was decided to complete the operation since the surgeons had started the vascular anastomosis. Shortly thereafter at $12: 30$, heart rate rose from 85 to 118 beats $\cdot \mathrm{min}^{-1}$, and peaked $\mathrm{T}$ waves occurred on the ECG, indicating hyperkalaemia. The patient was given a glucose-insulin infusion (ten units) and $90 \mathrm{mEq}$ of sodium bicarbonate for treatment of hypetkalaemia and acidosis. The patient's temperature began to rise at a rate of $0.1^{\circ} \mathrm{C}$ every two minutes, and a hyperdynamic circulatory pattern was apparent from the peripheral pulses and the iliac artery. Bags of frozen saline were placed in the axiliae, on the groin and around the neck. The patient was connected to an anaesthesia machine having no vaporizers and fresh soda lime, stored especially for such an instance; anaesthesia was continued with 100 per cent $\mathrm{O}_{2}$, incremental doses of fentanyl (to a total of $700 \mu \mathrm{g}$ ) and 3 mg diazepam. Before the vascular clamps were removed, the patient was given furosemide $1 \mathrm{mg} \cdot \mathrm{kg}^{-1}$ and mannitol $1 \mathrm{~g} \cdot \mathrm{kg}^{-1} \mathrm{IV}$.

At $12: 30$, after $200 \mathrm{mg}$ of dantrolene and an additional $90 \mathrm{mEq}$ of sodium bicarbonate, $\mathrm{PETCO}_{2}$ began to decrease and ventilation was slowed to 15 breaths $\cdot \mathrm{min}^{-1}$. Heart rate decreased from 120 beats $\cdot \mathrm{min}^{-1}$ to 100 beats $\cdot \mathrm{min}^{-1}$ at $13: 45$. However, at this time large $T$ waves consistent with marked hyperkaiaemia $(8.6$ $\mathrm{mEq} \cdot \mathrm{L}^{-1}$ ) occurred on $\mathrm{ECG}$, along with a short run of ventricular tachycardia that resolved spontaneously. Administration of an additional glucose-insulin infusion (ten units) and $1 \mathrm{~g}$ of calcium chloride resolved these electrocardiographic abnormalities. At this point, the surgeons were implanting the ureter into the bladder.

During the rest of the operation an additional $140 \mathrm{mg}$ of dantrolene was administered (total $3 \mathrm{mg} \cdot \mathrm{kg}^{-1}$ ). Vital signs were stable, and temperature remained constant at $37.3^{\circ} \mathrm{C}$. End-tidal $\mathrm{CO}_{2}$ levels fell to $26 \mathrm{mmHg}$ and potassium was $7.8 \mathrm{mEq} \cdot \mathrm{L}^{-1}$. Total urinary output was $650 \mathrm{ml}$. Fluids administered intraoperatively consisted of 2.7 L of saline, $1.5 \mathrm{~L}$ of lactated Ringer's solution and two units of packed red blood cells.

On arrival at the Intensive Care Unit, the patient was given $200 \mathrm{mg}$ of dantrolene; the CPK level was 271 units $\cdot \mathrm{L}^{-1}$ (upper limit of normal range 230 units $\cdot \mathrm{L}^{-1}$ ). While in the $\mathrm{ICU}$, the patient romained stable, and temperature did not increase. Dantrolene $200 \mathrm{mg}$ IV, was given every $6 \mathrm{hr}$ for $24 \mathrm{hr}$, following which the drug was given orally for another $24 \mathrm{hr}$. Twelve hours after surgery, the CPK level was 475 units $\cdot L^{-1}$, serum potassium 5.1 $\mathrm{mEq} \cdot \mathrm{L}^{-1}$, serum sodium $128 \mathrm{mEq} \cdot \mathrm{L}^{-1}$ and serum creatinine $7.9 \mathrm{mg} \mathrm{dL}^{-1}$. Urinary output was $13 \mathrm{~L}$ during the same period. Creatinine phosphokinase levels peaked (862 units $\cdot L^{-1}$ ) $36 \mathrm{hr}$ later, at which time serum potassium was $4.5 \mathrm{mEq} \cdot \mathrm{L}^{-1}$. The rest of the postoperative period was uneventful.

The patient's brother had previously received thiopentone and succinylcholine during anaesthetic induction and marked fasciculations were noted. Since no other abnormalities were detected the case proceeded under isoflurane anaesthesia. After this episode of malignant hyperthermia, the patient stated that he had had frequent leg cramps, as did his son, especially after ingestion of caffeine. He also said that an uncle had been "packed in ice" after an operative procedure. However, the patient refused to undergo muscle biopsy.

\section{Discussion}

This patient experienced hyperkalaemic, hypermetabolic and hyperthermic states compatible with $\mathrm{MH}$. The following occurrences suggested this diagnosis: a rapid increase in the end-tidal concentration of $\mathrm{CO}_{2}$ without change in the ventilatory pattern, a low oxygen partial pressure in venous blood, and a steady increase in lemperature $3 \mathrm{hr}$ after induction of anaesthesia. The slow onset of these signs may have been related to the use of an halogenated anaesthetic ${ }^{5}$ and decreased reflex responsiveness (by thiopentone) or neuromuscular transmission (by a non-depolarizing drug). ${ }^{1}$ This delayed clinical course, lack of muscle rigidity and relatively slight increase in CPK could be described as a non-rigid type of malignant hyperthermia. ${ }^{s}$

The marked increase in the serum potassium level that occurred approximately 90 minutes after induction was the first abnormality; initially this was attributed to renal failure. However, since baseline potassium values were normal and sodium decrcased simultaneously to very low values, these changes could be explained by an unusually early disruption of cell membrane homeostasis as a part of the $\mathrm{MH}$ syndrome. In fact, end-expiratory $\mathrm{PCO}_{2}$, temperature and pulse rate did not change until the onset of major changes in sodium and potassium (Table), suggesting that electrolyte abnormalities (as a reflection of membrane abnormalities) preceded hypermetabolism in this $\mathrm{MH}$ reaction. End-stage renal disease with previous electrolytes disturbances may play a role in this atypical response. Similarly, it is interesting to speculate if the late intra- and postoperative hyperkalaemia were related to some aspect of renal failure in spite of high urinary output. This situation might indicate a residual membrane alter- 
TABLE Changes in arterial and venous blood gases and electrolytes

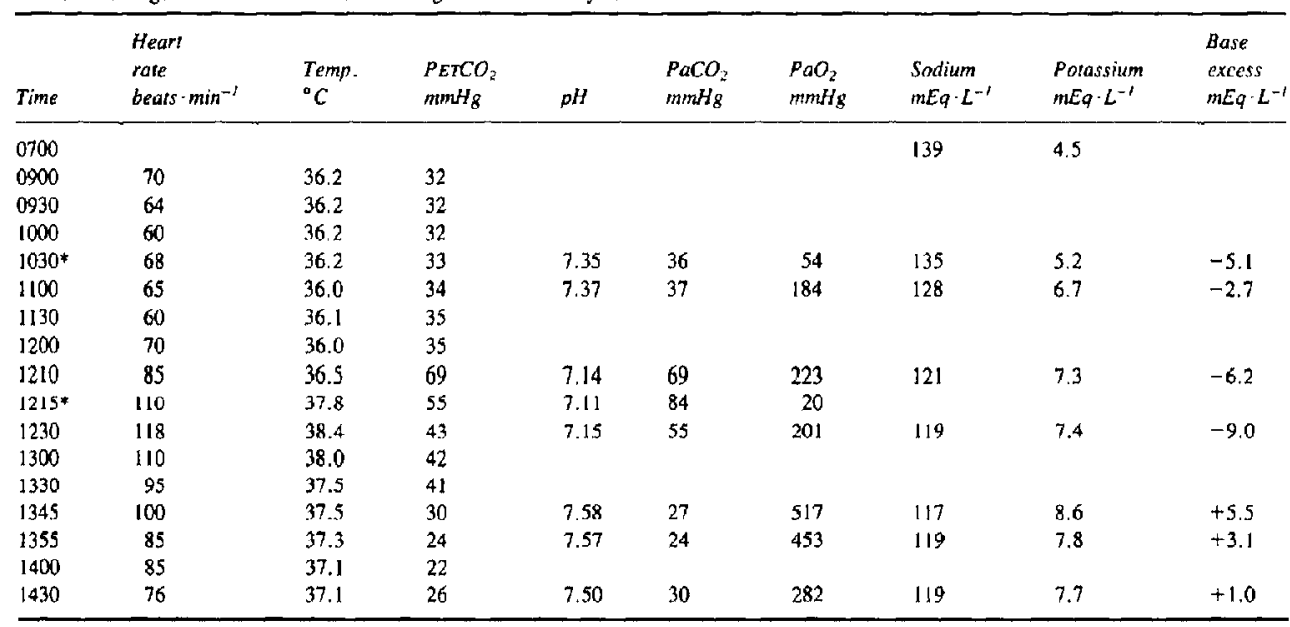

*From venous blood.

ation during normal temperature, $\mathrm{PETCO}_{2}$ and pulse rate

Although it has been reported that hyperkalaemia increases whole body metabolism in $\mathrm{MH}$ susceptible pigs $^{2}$ and induces abnormal contraction in susccptible human muscles in vitro, ${ }^{3}$ its relative contribution in this case could not be directly evaluated. Calcium administration (for the treatment of hyperkalaemia) is against the traditional teaching that calcium is contraindicated during an $\mathrm{MH}$ reaction. However, higher doses of calcium reportedly do not trigger $\mathrm{MH}$ in the heart or whole body of the highly susceptible Pietrain pig, a finding probably related to the large difference between intra- and extracellular concentration of free ionized calcium. ${ }^{2}$ The role of inhalation agents as triggers of $\mathrm{MH}$ is well known. Nitrous oxide is less likely to be a specific triggering agent $^{6}$ and its use is considered safer than isoflurane, which probably initiated the $\mathrm{MH}$ reaction in three patients ${ }^{7-9}$ although they had received succinylcholine for intubation. Recently, MH was reported during a pyelolithotomy in a patient anaesthetized with epidural bupivacaine and isoflurane in which vecuronium was the only neuromuscular blocking drug used. ${ }^{10}$ Halothane and vecuronium were used in the only report of $\mathrm{MH}$ during renal transplantation. ${ }^{5}$ Atracurium has been given to MH-susceptible pigs ${ }^{11,12}$ and patients ${ }^{13,14}$ without adverse effects. In summary, a successful management of a non-rigid type of $\mathrm{MH}$ in a living-related renal transplantation patient during isoflurane anaesthesia is described in which electrolyte abnormalities preceded signs of hypermetabolism.

\section{Acknowledgement}

The authors would like to thank Dr. G.A. Gronert for his advice.

\section{References}

1 Gronert GA. Milde JH. Variations in onset of procine malignant hyperthermia. Anesth Analg 1981; 60: 499-503.

2 Gronert GA, Ahern CP, Milde JH, White RD. Effect of $\mathrm{CO}_{2}$, calcium, digoxin, and potassium on cardiac and skeletal muscle metabolism in malignant hyperthernia sus* ceptible swine. Anesthesiology 1986; 64: 24-8.

3 Moulds RFW, Denborough MA Biochemical basis of malignant hyperpyrexia, Br Med J 1974; 2: 241-4.

4 Wade JG. Stevens WC. Isoflurane: an anesthetic for the eighties? Anesth Analg 1981; 60: 666-82.

5 Byers DJ, Merin RG. Malignant hyperthermia in a renal transplant patient. Anesthesiology 1987; 67: 979-81.

6 Ellis FR, Clarice IMC. Appleyard TN, Dinsdale RCW. Malignant hyperpyrexia induced by nitrous oxide and treated with dexamethasone. Br Med J 1974; 4: 270-1.

7 Joseph $M M$, Shah $K$, Viljoen JF. Malignant hyperthermia associated with isoflurane anesthesia. Anesth Analg 1982; 61: 711-12.

8 Boheler J, Hamrick JC Jr, MCKnight RL, Eger EI II, Isoflurane and malignant hyperthermia. Anesth Analg 1982; 61: 712-3.

9 Jensen $A G$, Bach $W$, Werner MU, Nielsen HK, Jensen $M H$. A fatal case of malignant hyperthermia following isoflurane anesthesia. 1986; 30: 293-4. 
10 Thomas $D W$, Dev VJ, Whitehead MJ. Malignant hyperpyrexia and isoflurane. Br J Anaesth 1987; 59: 1196-8.

II Skarpa M, Dayan AD, Follenfant $M$ et al. Toxicity testing of atracurium. Br J Anaesth 1983; 55 suppl 1: 27S-29S

12 Morrell DF, Harrison GG. The screening of atracurium in MHS swine. Br J Anaesth 1986; 58: 444-6.

13 Michel PA, Fronefield HP. Use of atracurium in a patient susceptible to malignant hyperthermia. Anesthesiology 1985; 62: 213 .

14 Ording $H$. Nielsen VG. Atracurium and its antagonism by neostigmine (plus glycopyrrolate) in patients susceptible to malignant hyperthermia. Br J Anaesth 1986; 58:

$1001-4$.

\section{Résumé}

Un homme 35 ans pesant $110 \mathrm{~kg}$ a développé une hyperkaliémie marquée, une hyponatrémie, une hypercapnie et une hyperthermie durant une transplantation rénale faite sous anesthésie à l'isofluranelprotoxyde d'azote et atracuriun. Ceci est le premier cas rapporté d' une hyperthermic maligne déclenchée par l'isoflurane durant une transplantation rénale avec un début précoce et des anomalies électrolytiques persistantes $(12$ heures après chirurgie). 